\title{
PENGARUH PELATIHAN DAN PENGALAMAN MENGAJAR TERHADAP PROFESIONALITAS GURU \\ (Studi pada Guru IPS Terpadu yang Memiliki Latar Belakang Pendidikan dalam Bidang Pendidikan Ekonomi)
}

\author{
Muhammad Rakib, Arfina Rombe, Muchtar Yunus \\ Universitas Negeri Makassar
}

\begin{abstract}
ABSTRAK
Tujuan penelitian ini adalah: 1) untuk menjelaskan pengaruh pelatihan terhadap profesionalitas guru, 2) untuk menjelaskan pengaruh pengalaman mengajar terhadap profesionalitas guru, dan 3) untuk menjelaskan pengaruh pelatihan, dan pengalaman mengajar terhadap profesionalitas guru. Populasi dalam penelitian ini adalah seluruh guru yang memiliki latar belakang pendidikan dalam bidang pendidikan ekonomi yang mengajarkan mata pelajaran IPS pada Sekolah Menengah Pertama di Kabupaten Toraja Utara yaitu sebanyak 132 orang, sedangkan sampel dalam penelitian ini berjumlah 98 responden. Penelitian ini menggunakan pendekatan kuantitatif jenis penelitian verifikatif dan menggunakan teknik pengumpulan data yaitu wawancara dan kuesioner. Alat analisis yang digunakan dalam penelitian ini adalah analisis statistik deskriptif dan analisis statistik inferensial. Hasil penelitian menunjukkan bahwa 1) Pelatihan secara parsial berpengaruh positif dan signifikan terhadap profesionalitas guru, 2) pengalaman mengajar secara parsial berpengaruh positif dan signifikan terhadap profesionalitas guru, dan 3) Pelatihan dan pengalaman mengajar secara silmultan berpengaruh positif dan signifikan terhadap profesionalitas guru.
\end{abstract}

Kata Kunci: Pelatihan, Pengalaman mengajar, profesionalitas guru.

\section{PENDAHULUAN}

Untuk menjadi guru profesional sangat dipengaruhi oleh tingkat keahlian dan pendidikan yang ditempuhnya. Dimana, jabatan pendidik merupakan jabatan profesi yang menuntut keahlian, tanggung jawab, dan kesetiaan profesi. Jabatan profesi tidak dapat diperoleh tanpa latihan atau persiapan untuk memiliki kompetensi yang dipersyaratkan. Pemerintah telah merumuskan empat jenis kompetensi guru sebagaimana tercantum dalam penjelasan Peraturan Pemerintah Nomor 19 Tahun 2005 tentang Standar Nasional Pendidikan, yaitu: kompetensi pedagogik, kompetensi kepribadian, kompetensi sosial, dan kompetensi profesional. Adanya peraturan pemerintah tersebut, para guru harus mengikuti atau melanjutkan pendidikan minimal ke jenjang strata satu (sarjana) untuk dapat menguasai empat kompetensi tersebut. Hal ini juga ditegaskan oleh Menteri Pendidikan Nasional melalui Permendiknas Nomor 16 Tahun 2007 menetapkan standar kualifikasi akademik dan kompetensi guru.

Selain itu, guru harus mengikuti pelatihan/penataran tentang model pembelajaran, pelatihan pembuatan alat peraga, pelatihan pengembangan silabus, pelatihan pembuatan materi, 
dan sebagainya. Melalui pelatihan tersebut, informasi-informasi baru dan metode-metode mengajar baru dapat cepat diterima oleh pendidik, sehingga dapat meningkatkan kemampuan dan motivasi dari para pendidik untuk melaksanakan pekerjaannya sehingga lebih profesional. Guru membutuhkan pelatihan profesional untuk menambah wawasan dan meningkatkan keterampilan mereka. Pelatihan itu akan lebih bermanfaat bagi guru jika guru memiliki semangat belajar seumur hidup. Guru dapat mengembangkan kompetensinya melalui belajar dari berbagai program pelatihan dari sekolah maupun luar sekolah.

Hasil penelitian terdahulu oleh Somantri dan Ridwan (2011) menyatakan bahwa pemberdayaan kelompok kerja guru (KKG) model implementasi lesson study kepada guru-guru yang tergabung dalam kelompok KKG khususnya di Kabupaten Seluma, efektif untuk meningkatkan kemampuan guru-guru dalam melakukan pembelajaran yang berfokus pada siswa. Dengan demikian kompetensi guru dan tenaga kependidikan dapat meningkat secara berkelanjutan dan akan bermuara pada peningkatan mutu proses dan hasil belajar siswa. Mulyawan (2012) menyatakan bahwa kegiatan pelatihan merupakan instrumen penunjang profesionalisme profesi guru dalam menjalankan kinerjanya.

Berdasarkan hasil observasi awal peneliti dan data yang diperoleh dari Dinas Pendidikan Kabupaten Toraja Utara bahwa guru mata pelajaran IPS Terpadu memiliki latar belakang pendidikan yang berbeda-beda, ada yang berasal dari bidang kependidikan dan ada dari non kependidikan. Akan tetapi, pada umumnya guru mata pelajaran IPS Terpadu di Kabupaten Toraja Utara memiliki latar belakang pendidikan dalam bidang pendidikan ekonomi dan ilmu ekonomi, hanya sedikit yang memiliki latar belakang pendidikan dalam bidang pendidikan lainnya (sejarah, geografi, hukum dan politik, sosiologi/antropologi, dan sebagainya). Walaupun mereka pada umumnya memiliki melatar belakang pendidikan dalam bidang pendidikan ekonomi, namun mereka dituntut mampu mengajarkan berbagai disiplin ilmu yang terhimpun dalam mata pelajaran IPS Terpadu seperti sejarah, geografi, ekonomi, hukum dan politik, sosiologi/antropologi, dan sebagainya.

Untuk mengantisipasi kondisi tersebut, pemerintah telah menyelenggarakan berbagai jenis pelatihan dalam peningkatan profesionalitas guru. Para guru mata pelajaran IPS Terpadu tersebut, memanfaatkan kesempatan itu untuk meningkatkan kompetensinya dalam menunjang profesionalitasnya, bahkan mereka juga aktif dalam Majelis Guru Mata Pelajaran (MGMP) IPS. Namun demikian, tentunya mereka tidak semua memiliki akses yang sama untuk ikut dalam setiap pelatihan yang dilaksanakan baik pemerintah maupun organisasi-organisasi kemasyarakatan di bidang pendidikan. Hal tersebut disebabkan faktor wilayah sekolah yang jauh dari pusat kota. Faktor penyebab yang paling menonjol adalah pada umumnya guru-guru yang memiliki pengalaman mengajar lebih lama lebih banyak mengikuti kegiatan-kegiatan seperti pelatihan kependidikan, seminar pendidikan, dan lain-lain, sebaliknya guru yang masih kurang pengalaman mengajarnya, lebih banyak mengajar di sekolah.

Berdasarkan permasalahan tersebut, dapat dikemukakan bahwa para guru tidak memiliki akses yang sama atau tidak merata dilihat dari jenis, intensitas, dan relevansinya dengan latar belakang pendidikannya dalam menunjang profesionalitasnya. Selain itu, mereka memiliki masa kerja/pengalaman mengajar yang berbeda sehingga juga berdampak pada kesempatan untuk meningkatkan profesionalitasnya. Oleh karena itu, penulis tertarik untuk mengkaji pengaruh 
Muhammad Rakib, Arfina Rombe, Muchtar Yunus, Pengaruh Pelatihan dan Pengalaman Mengajar terhadap

Profesionalitas Guru |139

pelatihan dan pengalaman Mengajar terhadap Profesionalitas Guru yang berlatar belakang pendidikan ekonomi yang mengajarkan mata pelajaran IPS pada Sekolah Menengah Pertama di Kabupaten Toraja Utara.

\section{KAJIAN TEORI}

Menurut Armstrong (2006) bahwa pelatihan bermanfaat untuk membantu guru mengembangkan keterampilan dan tingkat kemampuan guru. Suyatno (2008) mengemukakan pelatihan yaitu kegiatan yang dilakukan dalam rangka pengembangan atau peningkatan kompetensi dalam melaksanakan tugas sebagai pendidik, baik pada tingkat kecamatan, kabupaten/kota, provinsi, nasional, maupun internasional. Bukti fisik komponen ini dapat berupa sertifikat, piagam, atau surat keterangan dari lembaga penyelenggara diklat. Menurut Musfah (2011), pelatihan memiliki pengaruh yang sangat signifikan terhadap efektivitas sebuah sekolah. Pelatihan memberi kesempatan kepada guru untuk mendapatkan pengetahuan, keterampilan dan sikap baru yang mengubah perilakunya, yang pada akhirnya akan meningkatkan prestasi belajar siswa. Pelatihan harus sesuai dengan kebutuhan guru mengajar. Penyelenggara harus merencanakan dengan matang setiap pelatihan, mulai dari pemilihan materi, waktu, tempat, metode hingga kualitas instruktur.

Berdasarkan Peraturan Menteri Pendayagunaan Aparatur Negara dan Reformasi Birokrasi Nomor 16 Tahun 2009 dijelaskan bahwa pengembangan keprofesian berkelanjutan adalah pengembangan kompetensi guru yang dilaksanakan sesuai dengan kebutuhan, bertahap, berkelanjutan untuk meningkatkan profesionalitasnya. Pelatihan merupakan salah satu upaya untuk mengembangkan profesionalitas guru. Angka kredit adalah satuan nilai dari tiap butir kegiatan dan/atau akumulasi nilai butir-butir kegiatan yang harus dicapai oleh seorang guru dalam rangka pembinaan kepangkatan dan jabatannya. Dari uraian di atas dapat disimpulkan bahwa pelatihan guru merupakan kegiatan yang dilakukan dalam rangka pengembangan atau peningkatan kompetensi dalam melaksanakan tugas sebagai pendidik. Dari pengertianpengertian di atas, pelatihan berarti proses mengajarkan keahlian dan memberikan pengetahuan untuk mendapatkan dan meningkatkan keterampilan yang berkaitan dengan pekerjaan supaya dapat melaksanakan tanggung jawabnya sesuai dengan standar. Ini berbeda dari pendidikan yang memberikan pengetahuan terhadap suatu subyek tertentu secara umum, karena pelatihan memusatkan diri pada kebutuhan khusus dalam pekerjaan.

Pelatihan merupakan upaya pengembangan sumber daya manusia (guru). Menurut Departemen Pendidikan Nasional (2009) bahwa indikator yang akan dipakai untuk pelatihan yaitu: 1) Lama pelatihan. Semakin lama guru mengikuti pelatihan maka kemampuan dan ketrampilan guru akan bertambah sehingga dapat menunjang peningkatan proses pembelajaran, 2) Tingkat pelatihan. Tingkat pelatihan yang diikuti guru meliputi tingkat kecamatan, kabupaten/ kota, provinsi, nasional maupun internasional, dan 3) Relevansi. Pelatihan akan berperan besar dalam meningkatkan kemampuan dan ketrampilan guru apabila terdapat relevansi antara pelatihan yang diikuti dengan kebutuhan dan keadaan guru serta sesuai dengan perkembangan ilmu pengetahuan. 
140|Ad'ministrare, Vol. 3 No. 2, 2016

Menurut Suyatno (2008), pengalaman mengajar yaitu masa kerja guru dalam melaksanakan tugas sebagai pendidik pada satuan pendidikan tertentu sesuai dengan surat tugas dari lembaga yang berwenang (dapat dari pemerintah, dan/atau kelompok masyarakat penyelenggara pendidikan). Bukti fisik dari komponen ini dapat berupa surat keputusan/surat keterangan yang sah dari lembaga yang berwenang.

Di dalam menekuni bidangnya guru selalu bertambah pengalamannya. Semakin bertambah masa kerjanya diharapkan guru semakin banyak pengalaman-pengalamannya. Pengalaman-pengalaman ini erat kaitannya dengan peningkatan profesionalisme pekerjaan. Guru yang sudah lama mengabdi di dunia pendidikan harus lebih professional dibandingkan guru yang beberapa tahun mengabdi. Pengalaman mengajar adalah sesuatu yang di-miliki oleh seorang guru dalam memberikan pengeta-huan atau kecakapan-kecakapan atau keterampilan keterampilan kepada peserta didik dalam rangka pencapaian tujuan pembelajaran. Bentuk pengalaman mengajar di antaranya meliputi: (a) lama menjadi tenaga pengajar, (b) pengalaman penataran, (c) mengikuti pendidikan dan latihan, (d) seminar-seminar, dan pengalaman lain selama guru mengajar. Bagi seorang guru pengalaman meng-ajar mutlak diperlukan, karena guru memiliki peran yang sangat penting dalam menentukan kualitas pengajaran yang diberikan.

Menurut Suyatno (2008), masa kerja atau pengalaman mengajar dihitung sejak yang bersangkutan bekerja sebagai guru baik sebagai PNS maupun non PNS. Bagi guru non PNS harus ada bukti fisik bahwa yang bersangkutan mengajar pada sekolah tersebut. Menurut Widoyoko (2005) "Pengalaman mengajar pada hakekatnya merupakan rangkuman dari pemahaman seseorang terhadap hal-hal yang dialami dalam mengajar, sehingga hal-hal yang dialami tersebut telah dikuasinya, baik tentang pengetahuan, ketrampilan maupun nilai-nilai yang menyatu padanya".

Pengalaman mengajar merupakan salah satu faktor yang sangat menentukan keberhasilan dalam pendidikan. Pengalaman mengajar dalam hal ini adalah masa kerja selama menjadi guru. Lamanya masa kerja sebagai seorang guru akan memberikan pengalaman yang berbeda antara guru yang satu dan yang lain. Semakin lama dia menjabat sebagai guru, berarti semakin banyak pengalamannya, sehingga seorang guru yang mempunyai masa kerja lama tidak akan sama dengan guru yang baru. Seorang guru yang memiliki pengalaman mengajar dan masa kerja mengajar yang relatif lama, akan memiliki tingkat kemampuan atau prestasi kerja sebagai guru yang tinggi. Untuk mengukur tingkat pengalaman kerja seorang pegawai dapat dilihat dari;1) lama waktu/masa kerja, 2) tingkat pengetahuan dan keterampilan yang dimiliki, dan 3) penguasaan terhadap pekerjaan dan peralatan (Foster, 2001).

Selanjutnya, menurut Suyanto dan Djihad (2013) profesionalitas adalah suatu sebutan terhadap kualitas sikap para anggota suatu profesi terhadap profesinya serta derajat tugastugasnya. Dengan demikian, profesionalitas lebih menggambarkan suatu keadaan derajat keprofesian dilihat dari sikap, pengetaahuan dan keahlian yang diperlukan untuk melaksanakan tugasnya.

Menurut Usman (2006) bahwa kompetensi profesional secara spesifik dapat dilihat dari indikator-indikator sebagai berikut: 1) Menguasai landasan pendidikan, yaitu mengenal tujuan pendidikan, mengenal fungsi sekolah dan masyarakat, serta mengenal prinsip-prinsip psikologi 
pendidikan, 2) Menguasai bahan pengajaran, yaitu menguasai bahan pengajaran kurikulum pendidikan dasar dan menengah, menguasai bahan penghayatan, 3) Menyusun program pengajaran, yaitu menetapkan tujuan pembelajaran, memilih dan mengembangkan bahan pengajaran, memilih dan mengembang-kan strategi belajar mengajar, memilih media pembelajaran yang sesuai, memilih dan memanfaatkan sumber belajar, melaksanakan program pengaja-ran, menciptakan iklim belajar mengajar yang tepat, mengatur ruangan belajar, mengelola interaksi belajar mengajar, 4) Menilai hasil dan proses pembelajaran yang telah dilaksanakan.

Menurut Mulyasa (2007), ruang lingkup kompetensi profesional guru ditunjukkan oleh beberapa indikator. Secara garis besar indikator yang dimaksud adalah: 1) Kemampuan dalam memahami dan menerapkan landasan kependidikan dan teori belajar siswa; 2) Kemapuan dalam proses pembelajaran seperti pengembangan bidang studi, menerapkan metode pembelajajaran secara variatif, mengembangkan dan menggunakan media, alat dan sumber dalam pembelajaran, 3) Kemampuan dalam mengorganisasikan program pembelajaran, dan 4) Kemampuan dalam evaluasi dan menumbuhkan kepribadian peserta didik. Sementara itu Peraturan Pemerintah No 19 Tahun 2005 tentang Standar Pendidikan Nasional dalam kompetensi kepribadian disebutkan bahwa guru mencerminkan kepribadian yang dewasa dan dalam kompetensi sosial disebutkan bahwa guru harus mampu berkomunikasi dan bergaul secara efektif.

Berdasarkan beberapa pendapat di atas maka Indikator profesionalitas guru adalah: 1) Menguasai landasan pendidikan, 2) menguasai bahan pengajaran, 3) kemampuan menyusun program pengajaran, 4) kemampuan mengevaluasi, 5) kemampuan berkomunikasi, dan 6) kepribadian yang dewasa.

\section{METODE PENELITIAN}

Jenis penelitian ini adalah penelitian verifikatif yaitu penelitian yang bertujuan menelaah kausalitas antar variabel yang menjelaskan suatu fenomena tertentu untuk mejelaskan atau membuktikan hubungan atau pengaruh antar variabel yaitu bagaimana pengaruh Pelatihan dan Pengalaman Mengajar terhadap Profesionalitas Guru IPS yang berlatar belakang pendidikan dalam bidang pendidikan Ekonomi atau ilmu ekonomi di Kabupaten Toraja Utara kemudian masalah yang timbul oleh peneliti dilakukan gambaran atau lukisan secara sistematis, faktual, dan akurat mengenai fakta, sifat-sifat serta hubungan antara fenomena yang diselidiki. Penelitian ini dilaksanakan di Kabupaten Toraja Utara. Populasi penelitian yaitu seluruh guru IPS Terpadu yang memiliki latar belakang pendidikan dalam bidang pendidikan ekonomi dan ilmu ekonomi di Kabupaten Toraja Utara yang berjumlah 132 orang dan menarik sampel seecara probability sampling sebanyak 98 responden.Teknik pengumpulan data digunakan melalui angket dan wawancara, dan data yang telah dikumpulkan dianalisis dengan menggunakan analisis statistik deskriptif dan inferensial. 
142 |Ad'ministrare, Vol. 3 No. 2, 2016

\section{HASIL DAN PEMBAHASAN}

\section{Analisis Statistik Deskriptif}

Untuk mengetahui tingkat pelatihan guru IPS Terpadu yang memiliki latar belakang pendidikan dan bidang pendidikan ekonomi dapat dilihat tabel berikut ini.

Tabel 1 Tingkat Pelatihan Guru IPS Terpadu yang Memiliki Latar Belakang Pendidikan dalam Bidang Pendidikan Ekonomi di Kabupaten Toraja Utara

\begin{tabular}{clcc}
\hline Interval Kelas & \multicolumn{1}{c}{ Kategori } & Frekuensi & Persentase (\%) \\
\hline $63-75$ & Sangat tinggi & 20 & 20,41 \\
$51-62$ & Tinggi & 75 & 76,53 \\
$39-50$ & Cukup tinggi & 3 & 3,06 \\
$27-38$ & Rendah & 0 & 0,00 \\
$15-26$ & Sangat rendah & 0 & 0,00 \\
\hline & Jumlah & 98 & 100,00 \\
\hline
\end{tabular}

Tabel 1 menunjukkan bahwa pelatihan guru IPS Terpadu yang memiliki latar belakang pendidikan dalam bidang pendidikan ekonomi di Kabupaten Toraja Utara yaitu 75 responden atau 76,53 persen berada pada kategori tinggi dan skor rata-rata sebesar 60,94 dengan standar deviasi 5,27. Ini berarti tingkat pelatihan yang telah diikuti oleh guru IPS tinggi dilihat dari lamanya pelatihan, intensitas pelatihan, dan relevansi pelatihan. Semakin banyak pelatihan yang diikuti oleh guru maka akan semakin dapat meningkatkan kemampuan dan ketrampilan guru. Pelatihan akan berperan besar dalam meningkatkan kemampuan dan keterampilan guru apabila terdapat relevansi antara pelatihan yang diikuti dengan kebutuhan dan keadaan guru serta sesuai dengan perkembangan ilmu pengetahuan.

Tabel 2 Tingkat Pengalaman Mengajar Guru IPS Terpadu yang Memiliki Latar Belakang Pendidikan dalam Bidang Pendidikan Ekonomi di Kabupaten Toraja Utara

\begin{tabular}{clcc}
\hline Interval Kelas & \multicolumn{1}{c}{ Kategori } & Frekuensi & Persentase (\%) \\
\hline $63-75$ & Sangat berpengalaman & 79 & 80,61 \\
$51-62$ & Berpengalaman & 12 & 12,24 \\
$39-50$ & Cukup berpengalaman & 7 & 7,14 \\
$27-38$ & Kurang berpengalaman & 0 & 0,00 \\
$15-26$ & Tidak berpengalaman & 0 & 0,00 \\
\hline & Jumlah & 98 & 100,00 \\
\hline
\end{tabular}

Berdasarkan tabel 2, tingkat pengalaman mengajar guru IPS Terpadu yang memiliki latar belakang pendidikan dalam bidang pendidikan ekonomi yaitu 79 responden atau 80,61 persen berada pada kategori sangat berpengalaman dan skor rata-rata sebesar 64,49 dengan standar deviasi 5,182. Ini berarti guru IPS yang memiliki latar belakang pendidikan dalam 
bidang pendidikan ekonomi di Kabupaten Toraja Utara sangat berpengalaman dalam mengajar dilihat dari indikator masa kerja, keterampilan mengajar, dan penguasaan terhadap pekerjaan.

Selanjutnya, profesionalitas guru IPS yang memiliki latar belakang pendidikan dalam bidang pendidikan ekonomi di Kabupaten Toraja Utara dapat dilihat pada tabel berikut ini.

Tabel 3 Profesionalitas guru IPS Terpadu yang Memiliki Latar Belakang Pendidikan dalam Bidang Pendidikan Ekonomi di Kabupaten Toraja Utara

\begin{tabular}{clcc}
\hline Interval Kelas & \multicolumn{1}{c}{ Kategori } & Frekuensi & Persentase (\%) \\
\hline $126-150$ & Sangat tinggi & 26 & 26,53 \\
$104-125$ & Tinggi & 65 & 66,33 \\
$79-103$ & Cukup tinggi & 7 & 7,14 \\
$54-78$ & Rendah & 0 & 0,00 \\
$30-53$ & Sangat rendah & 0 & 0,00 \\
\hline & Jumlah & 98 & 100,00 \\
\hline
\end{tabular}

Berdasarkan tabel 3, profesionalitas guru IPS Terpadu yaitu 65 responden atau 66,33 persen dengan skor rata-rata sebesar 123,9 dan standar deviasi 8,315. Hal ini menggambarkan profesionalitas guru IPS yang memiliki latar belakang pendidikan dalam bidang pendidikan ekonomi di Kabupaten Toraja Utara tergolong sedang dilihat dari indikator tingkat penguasaan landasan pendidikan, penguasaan bahan pengajaran, kemampuan menyusun program pengajaran, kemampuan mengevaluasi, kemampuan berkomunikasi, dan kepribadian yang baik.

\section{Analisis Statistik Inferensial}

Analisis linear berganda pada penelitian ini bertujuan untuk mengetahui pengaruh pelatihan dan pengalaman mengajar terhadap profesionalitas guru IPS Terpadu yang memiliki latar belakang pendidikan dalam bidang pendidikan ekonomi di Kabupaten Toraja Utara.

\section{Uji t (Uji Parsial)}

Tabel 4 Pengaruh Pelatihan dan Pengalaman Mengajar secara Parsial terhadap Profesionalitas guru IPS Terpadu yang Memiliki Latar Belakang Pendidikan dalam Bidang Pendidikan Ekonomi

\begin{tabular}{|c|c|c|c|c|c|}
\hline \multirow{2}{*}{ Model } & \multicolumn{2}{|c|}{$\begin{array}{l}\text { Unstandardized } \\
\text { Coefficients }\end{array}$} & \multirow{2}{*}{$\begin{array}{c}\text { Standardized Coefficients } \\
\text { Beta }\end{array}$} & \multirow{2}{*}{$\mathrm{T}$} & \multirow{2}{*}{ Sig } \\
\hline & B & $\begin{array}{l}\text { Std. } \\
\text { Error }\end{array}$ & & & \\
\hline (Constant) & 27,950 & 7,133 & & 3,919 & 0,000 \\
\hline $\mathrm{X}_{1}$ & 0,758 & 0,105 & 0,480 & 7,248 & 0,000 \\
\hline$X_{2}$ & 0,772 & 0,106 & 0,481 & 7,254 & 0,000 \\
\hline
\end{tabular}

Pengaruh pelatihan terhadap profesionalitas. Nilai $t_{\text {hitung }}$ untuk variabel pelatihan sebesar 7,248 dengan nilai Sig. sebesar 0,000. Karena nilai sig. yang diperoleh $<0,05$, maka $\mathrm{H}_{0}$ ditolak 
144|Ad'ministrare, Vol. 3 No. 2, 2016

yang berarti bahwa pelatihan berpengaruh secara signifikan terhadap profesionalitas. Dengan demikian hipotesis yang berbunyi diduga ada pengaruh pelatihan terhadap profesionalitas guru IPS Terpadu yang memiliki latar belakang pendidikan dalam bidang pendidikan ekonomi di Kabupaten Toraja Utara "diterima".

Pengaruh pengalaman mengajar terhadap profesionalitas. Nilai $t_{\text {hitung }}$ untuk variabel motivasi sebesar 7,254 dengan nilai $\mathrm{p}$ (Sig.) sebesar 0,002. Karena nilai $\mathrm{p}$ yang diperoleh < 0,05 , maka $\mathrm{H}_{0}$ ditolak yang berarti bahwa pengalaman mengajar berpengaruh secara signifikan terhadap profesionalitas. Dengan demikian hipotesis yang berbunyi diduga ada pengaruh pengalaman mengajar terhadap profesionalitas guru IPS Terpadu yang memiliki latar belakang pendidikan dalam bidang pendidikan ekonomi di Kabupaten Toraja Utara "diterima".

Persamaan regresinya: $Y=27,950+0,758 X_{1}+0,772 X_{2}$. Persamaan ini menunjukkan bahwa ada pengaruh pelatihan, dan pengalaman mengajar terhadap profesionalitas guru IPS Terpadu yang memiliki latar belakang pendidikan ekonomi di Kabupaten Toraja Utara. Secara lebih rinci model regresi tersebut mengandung makna sebagai berikut:

a. Konstanta sebesar 27,950 , artinya jika pelatihan $\left(X_{1}\right)$ dan pengalaman mengajar $\left(X_{2}\right)$ nilainya 0 , maka profesionalitas guru IPS Terpadu yang memiliki latar belakang pendidikan dalam bidang pendidikan ekonomi (Y) nilainya sebesar 27,950.

b. Koefisien regresi variabel pelatihan $\left(\mathrm{X}_{1}\right)$ sebesar 0,758 , artinya jika variabel pelatihan $\left(\mathrm{X}_{1}\right)$ mengalami kenaikan 1 satuan dan pengalaman mengajar $\left(\mathrm{X}_{2}\right)$ tetap, maka profesionalitas guru IPS (Y) akan mengalami peningkatan sebesar 0,758. Koefisien bernilai positif artinya terjadi hubungan positif antara pelatihan dengan profesionalitas guru IPS Terpadu yang memiliki latar belakang pendidikan dalam bidang pendidikan ekonomi. Semakin tinggi tingkat pelatihan semakin tinggi pula profesionalitas guru IPS Terpadu yang memiliki latar belakang pendidikan dalam bidang pendidikan ekonomi tersebut.

c. Koefisien regresi variabel pengalaman mengajar $\left(\mathrm{X}_{2}\right)$ sebesar 0,772 , artinya jika variabel pengalaman mengajar $\left(\mathrm{X}_{2}\right)$ mengalami kenaikan 1 satuan dan pelatihan $\left(\mathrm{X}_{1}\right)$ tetap, maka profesionalitas guru IPS (Y) akan mengalami peningkatan sebesar 0,772. Koefisien bernilai positif artinya terjadi hubungan positif antara pengalaman mengajar dengan profesionalit Terpadu yang memiliki latar belakang pendidikan ekonomi as guru IPS Terpadu yang memiliki latar belakang pendidikan dalam bidang pendidikan ekonomi. Semakin banyak pengalaman yang dimiliki guru semakin tinggi pula profesionalitas guru IPS Terpadu yang memiliki latar belakang pendidikan dalam bidang pendidikan ekonomi tersebut.

\section{Uji F (Uji Simultan)}

Kriteria uji simultan adalah jika nilai $F$ hitung lebih besar dari $F$ tabel atau jika taraf signifikan F lebih kecil dari taraf signifikan yang digunakan (a) 0,05 maka hasil analisis secara simultan memiliki pengaruh yang signifikan. Jika hasil yang diperoleh adalah sebaliknya maka analisis tersebut secara tidak memiliki pengaruh yang signifikan secara simultan. 
Tabel 5 Pengaruh Pelatihan dan Pengalaman Mengajar Secara Simultan terhadap Profesionalitas Guru IPS Terpadu yang Memiliki Latar Belakang Pendidikan dalam bidang pendidikan Ekonomi di Kabupaten Toraja Utara.

\begin{tabular}{llccccc}
\hline & Model & $\begin{array}{c}\text { Sum of } \\
\text { Squares }\end{array}$ & Df & $\begin{array}{c}\text { Mean } \\
\text { Squres }\end{array}$ & F & Sig \\
\hline 1 & Regression & 4410,321 & 2 & 2205,160 & 91,215 & 0,000 \\
& Residual & 2296.659 & 95 & 24,175 & & \\
& Total & 6706,980 & 97 & & & \\
\hline
\end{tabular}

Tabel 5 menunjukkan bahwa nilai $\mathrm{F}_{\text {hitung }}$ sebesar 91,215 dengan nilai $p$ (Sig.) sebesar 0,000 . Karena nilai $\mathrm{p}<0,05$ maka $\mathrm{H}_{0}$ ditolak yang berarti bahwa terdapat pengaruh positif dan signifikan pelatihan dan pengalaman mengajar secara bersama-sama terhadap profesionalitas. Adapun besarnya pengaruh secara simultan dapat dilihat pada Tabel 6 yaitu $\mathrm{R}$ sebesar 0,811 atau sebesar 81,1 persen. Dengan demikian hipotesis yang berbunyi diduga ada pengaruh pelatihan dan pengalaman mengajar terhadap profesionalitas guru IPS Terpadu yang memiliki latar belakang pendidikan dalam bidang pendidikan ekonomi di Kabupaten Toraja Utara "diterima". Analisis ini digunakan dengan metode linear berganda dengan melihat persentase hubungan antara variabel bebas yang terdiri dari pelatihan dan pengalaman mengajar terhadap profesionalitas guru IPS Terpadu yang memiliki latar belakang pendidikan dalam bidang pendidikan ekonomi di Kabupaten Toraja Utara.

Tabel 6 Uji Determinasi Pelatihan dan Pengalaman Mengajar terhadap Profesionalitas Guru IPS Terpadu yang Memiliki Latar Belakang Pendidikan dalam bidang pendidikan Ekonomi di Kabupaten Toraja Utara.

\begin{tabular}{ccccc}
\hline Model & $\mathrm{R}$ & $\mathrm{R}$ Square & Adjusted R Square & Std. Error of the Estimate \\
\hline 1 & 0,811 & 0,658 & 0,650 & 4,917 \\
\hline
\end{tabular}

Tabel 6 menunjukkan bahwa nilai $R$ Square yang merupakan besaran nilai kontribusi pengaruh secara simultan pelatihan dan pengalaman mengajar terhadap profesionalitas guru IPS Terpadu yang memiliki latar belakang pendidikan ekonomi sebesar 0,658 atau 65,8 persen. Hal ini menunjukkan bahwa pelatihan dan pengalaman mengajar memiliki pengaruh yang kuat terhadap profesionalitas guru IPS Terpadu yang memiliki latar belakang pendidikan dalam bidang pendidikan ekonomi di Kabupaten Toraja Utara, sedangkan sisanya sebesar 34,2 persen merupakan nilai kontribusi pengaruh yang berasal dari variabel lainnya yang tidak dikaji dalam penelitian ini. 
146|Ad'ministrare, Vol. 3 No. 2, 2016

\section{Pembahasan}

\section{Pengaruh Pelatihan terhadap Profesionalitas Guru}

Hasil penelitian ini menunjukkan bahwa pelatihan berpengaruh terhadap profesionalitas guru. Hal ini didukung dengan hasil analisis deskriptif dalam penelitian ini menunjukkan bahwa pelatihan yang diikuti guru IPS Terpadu yang memiliki latar belakang pendidikan ekonomi di kabupaten Toraja Utara termasuk kategori tinggi dilihat dari indikator yaitu lamanya pelatihan yang diikuti, tingkat pelatihan dan relevansi.. Hasil analisis statistik deskriptif tentang pelatihan berada pada kategori tinggi. Sedangkan berdasarkan analisis data dengan menggunakan regresi linier menunjukkan adanya pengaruh yang signifikan pelatihan terhadap profesionalitas dengan nilai thitung untuk variabel pelatihan sebesar 7,248 dengan nilai $p$ (Sig.) sebesar 0,000. Karena nilai $\mathrm{p}$ yang diperoleh $<0,05$, maka $\mathrm{H}_{0}$ ditolak yang berarti bahwa pelatihan berpengaruh secara signifikan terhadap profesionalitas guru IPS Terpadu yang memiliki latar belakang pendidikan dalam bidang pendidikan ekonomi di Kabupaten Toraja Utara.

Hasil penelitian ini sejalan dengan apa yang telah kemukakan oleh Mulyawan (2012) bahwa pentingnya upaya meningkatkan profesional guru, baik secara kualitatif maupun kuantitatif yang perlu dilakukanterus menerus, sehingga kegiatan pelatihan merupakan instrumen penunjang profesionalisme profesi guru dalam menjalankan kinerjanya. Lebih lanjut, Suyatno (2008) mengemukakan pelatihan merupakan kegiatan yang dilakukan dalam rangka pengembangan atau peningkatan kompetensi dalam melaksanakan tugas sebagai pendidik, baik pada tingkat kecamatan, kabupaten/kota, provinsi, nasional, maupun internasional. Bukti fisik komponen ini dapat berupa sertifikat, piagam, atau surat keterangan dari lembaga penyelenggara diklat. Berdasarkan peraturan menteri pendayagunaan aparatur Negara dan reformasi birokrasi Nomor 16 Tahun 2009 dijelaskan bahwa pengembangan keprofesian berkelanjutan adalah pengembangan kompetensi guru yang dilaksanakan sesuai dengan kebutuhan, bertahap, berkelanjutan untuk meningkatkan profesionalitasnya. Pelatihan merupakan salah satu upaya untuk mengembangkan profesionalitas guru.

\section{Pengaruh Pengalaman Mengajar terhadap Profesionalitas Guru}

Hasil analisis deskriptif dalam penelitian ini menunjukkan bahwa pengalaman mengajar guru IPS SMP di kabupaten Toraja Utara termasuk kategori baik dilihat dari masa kerja guru, keterampilan mengajar dan penguasaan terhadap pekerjaan. Hasil penelitian menunjukkan bahwa pengalaman mengajar berada pada kategori sangat berpengalaman. Sedangkan berdasarkan analisis data degan menggunakan regresi linier diperoleh Nilai $t_{\text {hitung }}$ untuk variable pengalaman mengajar sebesar 7,254 dengan nilai $\mathrm{p}$ (Sig.) sebesar 0,000. Karena nilai $\mathrm{p}$ yang diperoleh $<0,05$, maka $\mathrm{H}_{0}$ ditolak yang berarti bahwa pengalaman mengajar berpengaruh secara signifikan terhadap profesionalitas guru IPS Terpadu yang memiliki latar belakang pendidikan dalam bidang pendidikan ekonomi di Kabupaten Toraja Utara.

Hasil uji hipotesis menunjukkan bahwa pengalaman mengajar berpengaruh signifikan terhadap profesionalitas. Hal ini sejalan dengan hasil penelitian Eliyanto dan Wibowo (2013) bahwa pengalaman mengajar berpengaruh positif dan signifikan terhadap profesionalisme guru. 
Muhammad Rakib, Arfina Rombe, Muchtar Yunus, Pengaruh Pelatihan dan Pengalaman Mengajar terhadap

Profesionalitas Guru |147

Dengan demikian, dapat dikatakan bahwa semakin lama atau banyak pengalaman mengajar guru maka akan semakin tinggi pula profesionalitasnya.

Menurut Suyatno (2008), pengalaman mengajar yaitu masa kerja guru dalam melaksanakan tugas sebagai pendidik pada satuan pendidikan tertentu sesuai dengan surat tugas dari lembaga yang berwenang (dapat dari pemerintah, dan/atau kelompok masyarakat penyelenggara pendidikan). Bukti fisik dari komponen ini dapat berupa surat keputusan/surat keterangan yang sah dari lembaga yang berwenang. Di dalam menekuni bidangnya guru selalu bertambah pengalamannya. Semakin bertambah masa kerjanya diharapkan guru semakin banyak pengalaman-pengalamannya. Pengalaman-pengalaman ini erat kaitannya dengan peningkatan profesionalisme pekerjaan.

Ada beberapa hal juga untuk menentukan berpengalaman tidaknya seorang pegawai yang sekaligus sebagai indikator pengalaman kerja menurut (Foster, 2001) yaitu: a) Lama waktu/masa kerja. Ukuran tentang lama waktu atau masa kerja yang telah ditempuh seseorang dapat memahami tugas - tugas suatu pekerjaan dan telah melaksanakan dengan baik. b) Tingkat pengetahuan dan keterampilan yang dimiliki. Pengetahuan merujuk pada konsep, prinsip, prosedur, kebijakan atau informasi lain yang dibutuhkan oleh karyawan. Pengetahuan juga mencakup kemampuan untuk memahami dan menerapkan informasi pada tanggung jawab pekerjaan. Sedangkan keterampilan merujuk pada kemampuan fisik yang dibutuhkan untuk mencapai atau menjalankan suatu tugas atau pekerjaan. c) Penguasaan terhadap pekerjaan dan peralatan. Tingkat penguasaan seseorang dalam pelaksanaan aspek-aspek teknik peralatan dan teknik pekerjaan.

\section{Pengaruh Pelatihan dan Pengalaman Mengajar terhadap Profesionalitas Guru}

Berdasarkan analisis data dengan menggunakan program SPSS Dari tabel annova diperoleh nilai $\mathrm{F}_{\text {hitung }}$ sebesar 91,215 dengan nilai $p$ (Sig.) sebesar 0,000. Karena nilai $\mathrm{p}<0,05$ maka $\mathrm{H}_{0}$ ditolak yang berarti bahwa terdapat pengaruh signifikan pelatihan dan pengalaman mengajar secara bersama-sama terhadap profesionalitas. Besarnya pengaruh tersebut dilihat pada nilai $\mathrm{R}$ Square $\left(\mathrm{R}^{2}\right)$ yaitu 0,658 atau $65,8 \%$. Artinya terdapat pengaruh signifikan antara pelatihan dan pengalaman mengajar secara simultan terhadap profesionalitas guru IPS Terpadu yang memiliki latar belakang pendidikan dalam bidang pendidikan ekonomi di Kabupaten Toraja Utara. Dengan demikian, hasil penelitian ini adalah pelatihan dan pengalaman mengajar secara bersama-sama berpengaruh terhadap profesionalitas guru IPS Terpadu yang memiliki latar belakang pendidikan dalam bidang pendidikan ekonomi di Kabupaten Toraja Utara. Pelatihan mempengaruhi profesionalitas guru. Berdasarkan analisis deskriptif persentase untuk variabel pelatihan dalam kategori baik, artinya pelatihan yang diikuti guru sudah baik, dan hal tersebut berpengaruh terhadap profesionalitas guru menjadi lebih baik. Dengan sering mengikuti pelatihan yang relevan sesuai dengan kebutuhan guru dapat meningkatkan profesionalitas guru. Ini berarti pelatihan dan pengalaman mengajar merupakan bagian yang tidak terpisahkan dari profesionalitas. 
148|Ad'ministrare, Vol. 3 No. 2, 2016

\section{SIMPULAN}

Berdasarkan hasil penelitian dan pembahasan dapat disimpulkan bahwa (1) Pelatihan berpengaruh positif dan signifikan terhadap profesionalitas guru IPS Terpadu yang memiliki latar belakang pendidikan dalam bidang pendidikan ekonomi di Kabupaten Toraja Utara, 2) Pengalaman mengajar berpengaruh positif dan signifikan terhadap profesionalitas guru IPS Terpadu yang memiliki latar belakang pendidikan ekonomi di Kabupaten Toraja Utara, dan 3) Pelatihan dan pengalaman mengajar secara silmultan berpengaruh positif dan signifikan terhadap profesionalitas guru IPS Terpadu yang memiliki latar belakang pendidikan dalam bidang pendidikan ekonomi di Kabupaten Toraja Utara di Kabupaten Toraja Utara. Tingkat Pelatihan meliputi lamanya pelatihan, intensitas pelatihan, dan relevansi pelatihan, dan pengalaman mengajar guru meliputi masa kerja guru, keterampilan mengajar dan penguasaan materi sangat memengaruhi peningkatan profesionalitas guru.

\section{DAFTAR PUSTAKA}

Armstrong, M. 2006. A Handbook of Human Resource Management Practice. 10th Edition. London: Kogan Page Limited.

Departemen Pendidikan Nasional. 2009. Pedoman Penyusunan Portofolio. Jakarta: Departemen Pendidikan Nasional.

Eliyanto, E., dan Wibowo, U. B. 2013. Pengaruh Jenjang Pendidikan, Pelatihan, Dan Pengalaman Mengajar Terhadap Profesionalisme Guru Sma Muhammadiyah Di Kabupaten Kebumen. Jurnal Akuntabilitas Manajemen Pendidikan. Vol 1, No 1 (2013) h. 34-47.

Foster, B. 2001. Pembinaan untuk Peningkatan Kinerja Karyawan. Jakarta: PPM.

Mulyasa. 2007. Standar Kompetensi dan Sertifikasi Guru. Bandung: PT. Remaja Rosdakarya.

Mulyawan, B. 2012. Pengaruh Pelatihan dalam Pengalaman terhadap Peningkatan Kompetensi Profesional Guru, Jurnal Ilmiah Ilmu Sosial. Volume 11 No. 1 (2012), h. 45-64.

Musfah, J. 2011. Peningkatan Kompetensi Guru melalui Pelatihan dan Sumber Belajar Teori dan Praktik. Jakarta: Kencana.

Peraturan Menteri Pendayagunaan Aparatur Negara dan Reformasi Birokrasi Nomor 16 Tahun 2009 tentang Jabatan Fungsional Guru dan Angka Kreditnya.

Peraturan Pemerintah Nomor 19 Tahun 2005 tentang Standar Nasional Pendidikan.

Permendiknas No. 16 Tahun 2007 tentang Standar Kualifikasi Akademik dan Kompetensi Guru. Somantri, M. dan Ridwan, S. 2011. Revitalisasi Kelompok Kerja Guru Guna Meningkatkan kompetensi dan Profesionalisme Guru SD/MI di Kabupaten seluma. Jurnal Kependidikan Triadik, (Online), Vol. 14 No. 1, (Diakses 14 April 2016).

Suyanto dan Djihad A, 2012. Bagaimana Menjadi Calon Guru dan Guru Profesional. Yogyakarta: Multi Pressindo.

Suyatno. 2008. Panduan Sertifikasi Guru. Jakarta: Indeks.

Usman, U. 2006. Menjadi Guru Profesional. Bandung: Remaja Rosda Karya.

Widoyoko, E. P. S. 2005. Kompetensi Mengajar Guru IPS Kabupaten Purworejo. Dirjen Dikti. 